\section{Ophthalmic Research}

Ophthalmic Res 2006;38:176

DOI: $10.1159 / 000093067$
Published online: May 5, 2006

\title{
Classification of Corneal Dystrophies
}

The fact is surprising that 5 corneal dystrophies (CD) that were previously believed to be distinct clinicopathologic entities are closely related at the molecular level to the different phenotypes resulting from distinct mutations in the transforming growth factor- $\beta$-induced gene (TGF- $\beta$ ) located on chromosome 5q31 [1]. El-Ashry et al. [2] also confirm this observation in their clinical and genetic study on a British population in which they examined familiar and sporadic patients with CDBII (ThielBehnke CD), GCD (granular CD, type I) and lattice CD, type I. The authors conclude that the genetic classification is much more accurate than the histological or the clinical description of the diagnosis of such disorders.

However, the ophthalmologist is the first to examine a new patient with a corneal dystrophy using the slit lamp. Therefore, he must have a clear and unmistakable nomenclature for the individual $\mathrm{CD}$ at his disposal. The eventual DNA examinations of the patient and maybe of other family members may or may not confirm his clinical diagnosis. The clinical classification has to describe briefly the individual landmarks of these diseases, for example, Meesmann CD with solitary perlucide epithelial microcysts.

In the past, ophthalmo-pathologists have also attempted to introduce other designations such a 'anterior limiting membrane dystrophy, type I (ALMDI) or corneal dystrophy of Bowman's layer, type I (CDBI)' for Reis-Bücklers $\mathrm{CD}$ and 'anterior limiting membrane dystrophy, type II (ALMDII) or corneal dystrophy of Bowman's layer, type II (CDBII)' for the Thiel-Behnke CD. Although they have some histological justification, these etiologically controversial new designations have not clarified the matter. On the contrary, they cause further confusion.

Until today, the nomenclature of the CD in the renowned ophthalmologic journals is not uniform. For example for the Reis-Bücklers CD you can find the following synonyms: superficial granular $\mathrm{CD}$, atypical granular $\mathrm{CD}$, granular CD, type III, ALMDI, CDBI. The histological changes in the Reis-Bücklers $C D$ and in the granular CD, type I are similar but the clinical appearance and follow-up of both diseases is completely different.

I propose that the corneal societies in the USA, Europe and Japan elaborate on the internationally accepted classification of CD. The Annual Symposium of The Cornea Society in corporation with the Annual Meeting of the AAO would be the best platform for this proposal. It would be desirable if finally in the future a uniform nomenclature for these diseases could be used in the ophthalmologic journals.

Walter Lisch, Hanau, Germany

\begin{tabular}{ll}
\hline KARGER & ( ) 2006 S. Karger AG, Basel \\
0030-3747/06/0384-0176\$23.50/0 \\
$\begin{array}{l}\text { Fax +4161306 1234 } \\
\begin{array}{l}\text { E-Mail karger@karger.ch } \\
\text { www.karger.com }\end{array}\end{array}$ & $\begin{array}{l}\text { Accessible online at: } \\
\text { www.karger.com/ore }\end{array}$
\end{tabular}

